\title{
Predicting Dye Biodegradation from Redox Potentials
}

\author{
Andrea Zille, ${ }^{\dagger}$ Patricia Ramalho, ${ }^{\ddagger}$ Tzanko Tzanov, ${ }^{\dagger}$ Roy Millward, ${ }^{\dagger}$ Veronika Aires, ${ }^{\dagger}$ \\ Maria Helena Cardoso,` Maria Teresa Ramalho,§ Georg M. Gubitz," and \\ Artur Cavaco-Paulo*,t
}

Department of Textile Engineering, University of Minho, 4800-058 Guimarães, Portugal, Departments of Biology and Chemistry, University of Minho, 4710-057 Braga, Portugal, and Department of Environmental Biotechnology, Graz University of Technology, 8010 Graz, Austria

\begin{abstract}
Two biological approaches for decolorization of azo sulfonated dyes have been compared: reductive decolorization with the ascomycete yeast I ssatchenkia occidental is and enzymatic oxidative decolorization with Trametes villosa laccase al one or in the presence of the mediator 1-hydroxybenzotriazole. The redox potential difference between the biological cofactor involved in the reductive activity of growing cells and the azo dye is a reliable indication for the decolorization ability of the biocatalyst. A linear relationship exists between the redox potential of the azo dyes and the decol orization efficiency of enzyme, enzyme/mediator, and yeast. The less positive the anodic peak of the dye, the more easily it is degraded oxidatevely with laccase. The more positive the cathodic peak of the dye, the more rapidly the dye molecule is reduced with yeast.
\end{abstract}

\section{Introduction}

Azo dyes are the largest group of synthetic dyes, applied to all fiber types. However, during the dyeing process not all of the dye is fixed on the textile material and up to $50 \%$ may be lost in the waste streams, depending on the dye type, depth of shade, and dyeing process. Conventional treatments of textile mill effluents do not remove efficiently most of these dyes (1). Biodegradability of the azo chromophores is based on oxidation and/or reduction reactions with enzymes, bacteria, or fungi (2). Under aerobic, anaerobic, or sequential anaerobic-aerobic treatments many bacteria reduce the azo bonds in dye molecules to aromatic amines, by the activity of low specificity azo-reductases (3-5). However, the azo dyes and their reductive biotransformation products (aromatic amines) have been shown to be toxic and in some cases mutagenic (6). Therefore, accumulation of these compounds should be avoided by using alternative dye decol orization approaches.

Laccase (EC 1.10.3.2) is a multicopper oxidase, which reduces oxygen to water and simultaneously performs one-electron oxidation of many aromatic substrates such as phenols and aromatic amines $(7,8)$. This enzyme decolorizes some azo dyes without direct cleavage of the azo bond through a highly nonspecific free radical mechanism, thereby avoiding the formation of toxic aromatic amines (9). H owever, the substrate specificity of laccase limits the number of azo dyes that can be degraded. To solve this problem laccase/mediator systems are normally used to broaden the range of azo dyes and to increase the decolorization rates (10-12)

* To whom correspondence should be addressed. Fax: +351253 510293. Email: artur@det.uminho.pt.

† Department of Textile Engineering, University of Minho.

‡ Department of Biology, University of Minho.

$\S$ Department of Chemistry, University of Minho.

" Graz University of Technology.
The ability of the bioagents to degrade azo dyes depends on the structural characteristics of the dye, the temperature and $\mathrm{pH}$ of treatment, the presence of intermediates, and the difference between the redox potentials of the biocatalyst and the dye. This study discusses the biodegradation under aerobic conditions of azo dyes with yeasts with reducing activity and an oxidative enzyme laccase with or without mediator. These two approaches have been compared on the basis of the electrochemical properties of dyes and bioagents (1315) The question targeted by this paper is whether the redox potential is a preliminary tool to predict the decolorization capacity of oxidative and reductive biocatalysts.

\section{Materials and Methods}

Dyes and Reagents. The structures of the dyes and the mediator tested in the present work are depicted in Chart 1. Dyes I and III (minimum 90\% dye content) were synthesized by the conventional method of coupling the diazonium salt of methanilic acid with either N,Ndimethyl-p-phenylenediamine or 1-amino-2-naphthol (16). The structures of the isolated dyes, as sodium salts, were confirmed by ${ }^{1} \mathrm{H}$ NMR spectroscopy in dymethylsulfoxide (DMSO). All other reagents and dyes were purchased from Sigma-Aldrich and used without further purification.

Enzyme. Laccase (EC 1.10.3.2) from Trametes villosa (5.3 $\mathrm{mg}$ protein $/ \mathrm{mL}, 600 \mathrm{U} / \mathrm{mL}$, supplied from Novo Nordisk, Denmark) was used for dye decolorization at pH 5 (0.1 M Na acetate buffer) as previously described (17).

Microorganism. The ascomycete yeast Issatchenkia occi dentalis (Portuguese Yeast Culture Coll ection 5770) was isolated on the basis of its capacity to decolorize agar plates containing yeast extract/peptone/glucose 0.5:1:2 (\% $\mathrm{w} / \mathrm{v}$ ) and the azo dye Orange II , as described in a previous publication (18). 
Chart 1. Dye and Mediator Structures<smiles>CN(C)c1ccc(N=Nc2cccc(S(N)(=O)=O)c2)cc1</smiles>

I) 3-(4-dimethylamino-phenylazo)-benzene

sulfonic acid sodium salt

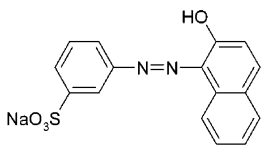

III)

3-(2-hydroxy-naphthalen-1-phenylazo)-

benzene sulfonic acid sodium salt

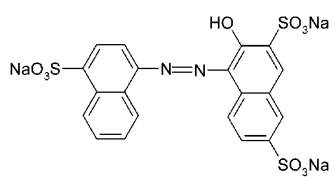

V) Acid red 27

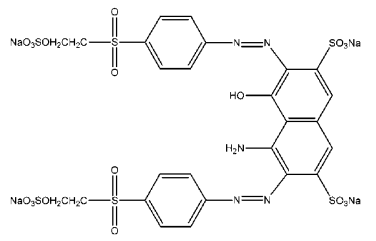

VII) Reactive Black 5

Decolorization with Laccase and Laccase/Mediator System. Dye solutions $(0.1 \mathrm{mM} ; 2.5 \mathrm{~mL})$ buffered with $0.1 \mathrm{M} \mathrm{Na}$ acetate buffer, $\mathrm{pH} \mathrm{5}$, were incubated with $20 \mu \mathrm{L}$ of laccase $(5.3 \mathrm{mg}$ protein $/ \mathrm{mL}, 600 \mathrm{U} / \mathrm{mL}$ ) and 0.5 $\mathrm{mL}$ of distilled water in a standard stirred cuvette at 25 ${ }^{\circ} \mathrm{C}$. The dye absorbance was measured at different times during the experiment and the percentage of effluent decolorization thereof was calculated. In the case of experiments with mediator the water volume $(0.5 \mathrm{~mL})$ was replaced by $0.1 \mathrm{mM}$ aqueous solution of 1-hydroxybenzotriazole (HBT).

Dye Decolorization with Microorganism. Decolorization experiments by growing cultures of I. occidental is were typically performed in $250 \mathrm{~mL}$ cotton-plugged Erlenmeyer flasks with $100 \mathrm{~mL}$ of sterile medium (normal decolorization medium, NDM) containing 2\% glucose, as carbon and energy source, and $0.2 \mathrm{mM}$ tested dye, in a mineral salts base, as previously described (19). The flasks were incubated under orbital shaking (120 rpm) at $26{ }^{\circ} \mathrm{C}$. Dye concentration was monitored by absorbance readings of centrifuged medium aliquots at the dye $\lambda_{\max }$. The assay cuvette contained $0.3 \mathrm{~mL}$ of $1 \mathrm{M}$ acetate buffer (pH 4.0), sample, and water to $3.0 \mathrm{~mL}$; the blank was prepared with the same dilution of buffer in distilled water.

Electrochemical Measurements. Cyclic voltammetry of the azo dyes was performed using a Voltalab 30 potentiostat (Radiometer Analytical, France), controlled

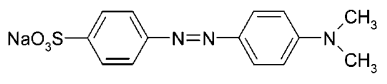

II) Acid Orange 52

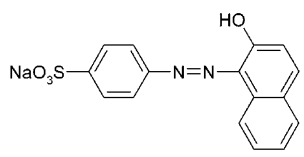

IV) Acid Orange 7

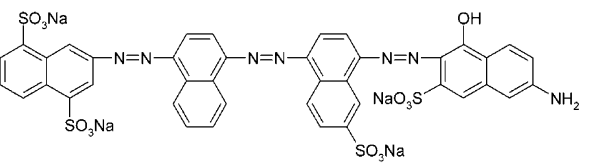

VI) Direct blue 71<smiles>On1nnc2ccccc21</smiles>

HBT - 1-HydroxyBenzoTriazole

by the Voltamaster 4 electrochemical software, at $100 \mathrm{mV}$ $\mathrm{s}^{-1}$ scan rate. The working, counter, and reference electrodes were, respectively, a glassy carbon electrode $\left(0.07 \mathrm{~cm}^{2}\right)$, coiled platinum wire $(23 \mathrm{~cm})$, and an $\mathrm{Ag} \mid \mathrm{AgCl}$ electrode filled with $3 \mathrm{M} \mathrm{NaCl}$, all purchased from BAS, USA. The glassy carbon electrode was successively polished with $5,1,0.3$, and $0.05 \mu \mathrm{m}$ alumina polish (Buehler Ltd, USA) and then rinsed with $8 \mathrm{M}$ nitric acid and distilled water before use. The experiments were performed in $0.1 \mathrm{M}$ acetate buffer pH 5 at dye concentration of $0.1 \% \mathrm{w} / \mathrm{v}$. Prior to analysis all solutions were purged with nitrogen for $15 \mathrm{~min}$. The redox potentials recorded vs $\mathrm{Ag} \mid \mathrm{AgCl}$ reference electrode were corrected by $0.206 \mathrm{~V}$ to the standard hydrogen electrode (SHE). Redox potentials of $\mathrm{T}$. villosa laccase, 1-hydroxybenzotriazole, and nicotinamide adenine dinucleotide phosphate (NADH) were provided from the literature and are as follows: laccase +780, HBT +1.084, and NADH -320 $\mathrm{mV}$ vs NHE (20-22).

\section{Results and Discussion}

Cyclic Voltammetry of Azo Dyes. The azo dyes tested in this study presented similar cyclic voltammograms illustrated by the voltammogram of dye I (Figure 1 ), in both positive and negative scans. In the first positive scan of dye I an irreversible anodic peak $\left(\mathrm{II}_{\mathrm{a}}\right)$ in the potential range of +0.9 to $+1.3 \mathrm{~V}$ vs $\mathrm{NHE}$ was observed. All dyes displayed an irreversible reduction 


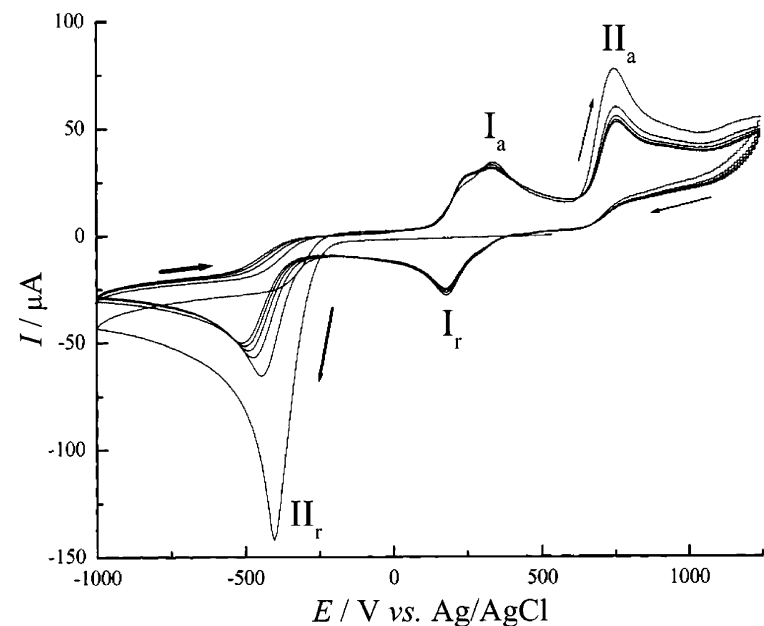

Figure 1. Cyclic voltammogram of dye I: (thin line) positive to negative, (thick line) negative to positive; 6 cycles at $100 \mathrm{mV}$ $\mathrm{s}^{-1}$ scan rate.

peak in the range of -0.13 to $-0.48 \mathrm{~V}$ vs NHE $\left(\mathrm{II}_{\mathrm{r}}\right)$. In the following scans an apparently semireversible redox couple $\left(I_{a}, I_{r}\right)$ was detected. The reductive wave $I_{r}$ of the semireversible redox couple did not appear in the first negative scan. These redox couple peaks appear to be associated with the formation of unstable amine products, which were oxidized in the range of +0.15 to $+0.58 \mathrm{~V}$ vs $\mathrm{NHE}$ and reduced in the potential range of -0.1 to +0.3 $\checkmark$ vs NHE.

The redox peaks $\mathrm{II}_{\mathrm{a}}$ and $\mathrm{II}_{\mathrm{r}}$ can be associated with irreversi ble redox reactions leading to cl eavage of the azo bonds. In the voltammograms of dyes VI (triazo) and VII (biazo) the number of oxidation peaks was higher than that observed for monoazo dyes. These peaks resulted from the oxidation of the amine products generated during the disruption of more than one azo bond in these dye molecules. To confirm this theory the cyclic voltagrams of the pure amine product solutions were performed separately. The results peaks could be overlaid, respectively, to the peaks I and II in the azo dye vol tammograms (data not shown).

Decolorization with Laccase. It has been reported that the chemical structures of the dyes largely influence their decolorization rates with laccase and that its decolorization efficiency was limited to several azo dye structures $(9,23)$. A correlation between the enzyme redox potential and its activity toward the substrates has also been described $(24,25)$. The driving force for a redox reaction is expected to be proportional to the difference between the redox potentials of oxidant and reductant. For laccase-mediated oxidations, an increase in the substrate redox potential should ther efore decrease the efficiency of the reaction. This hypothesis was tested by measuring the percentage of decolorization of each dye in the presence of laccase alone or laccase + HBT after $1 \mathrm{~h}$ of incubation. The observed results are summarized in Table 1, together with the respective anodic peak potential (26). The potential of the anodic peak gives the "degradation potential" where the degradation occurs in an irreversible redox reaction. As seen in Figure 2, a remarkably good linear correlation was found, in both systems, between the percentage decolorization of each dye and the respective anodic peak potential. The linear relationship was preserved for up to $2 \mathrm{~h}$, during the initial period of decolorization. When the maximum of decolorization was reached, the linearity disappeared. An important observation is that the anodic peak potentials of all the dyes are higher than the reported redox
Table 1. Percent Decolorization with Laccase or Laccase + HBT and Oxidation Peak Potentials (vs NHE) of Tested Azo Dyes

\begin{tabular}{llcc}
\hline & \multicolumn{2}{c}{$\%$ decolorization $( \pm$ SD) } & \\
\cline { 2 - 3 } dye & laccase & laccase + HBT & oxidation peak ${ }^{\mathrm{a}}(\mathrm{V})$ \\
\hline I & $71 \pm 3$ & $95 \pm 6$ & +0.961 \\
II & $76 \pm 6$ & $93 \pm 5$ & +0.965 \\
III & $90 \pm 5$ & $89 \pm 7$ & +0.952 \\
IV & $91 \pm 5$ & $94 \pm 7$ & +0.996 \\
V & $15 \pm 3$ & $66 \pm 4$ & +1.260 \\
VI & $50 \pm 4$ & $87 \pm 5$ & +1.091 \\
VII & $0.6 \pm 0.2$ & $65 \pm 4$ & +1.305
\end{tabular}

a Potentials (vs $\mathrm{Ag} / \mathrm{AgCl}(3 \mathrm{M} \mathrm{NaCl})$ and corrected to NHE) were recorded in both laccase and laccase/mediator system without significative change in potential.

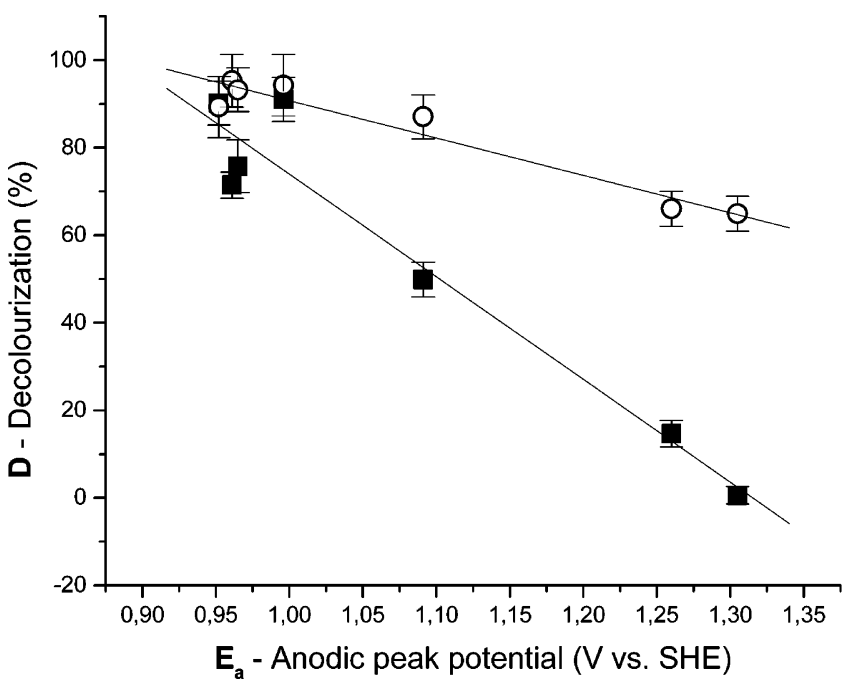

Figure 2. Correlation between anodic peak potential $\left(E_{a}\right)$ and decolorization $\%$ of azo dyes after $1 \mathrm{~h}$ with (ם) laccase and $(O)$ laccase/HBT mediator system. Correlation: $D(\boldsymbol{\square})=(308.6 \pm$ 28.9) - (234.6 \pm 26.6$) \mathrm{E}_{\mathrm{a}}, \mathrm{r}^{2}=0.97, \mathrm{SD}= \pm 9.7 ; \mathrm{D}(\mathrm{O})=(176.1$ $\pm 10.8)-(85.4 \pm 9.9) E_{a}, r^{2}=0.97, S D= \pm 3.6$

potential for $\mathrm{T}$. villosa laccase $(+0.780 \mathrm{~V}$ vs NHE) and, even so, most of them were extensively decolorized by laccase. The exceptions were dyes V and VII, for which were found high oxidation potentials (Table 1). These facts can be understood in the light of the Nernst equation. Any redox reaction is dependent on the formal redox potential and on the concentrations of the reduced and oxidized species. The laccase dye ratio in our system is about 1:1000 or more to the dye. These concentration differences can explain why laccase can oxidize such dyes high degradation potential.

Concerning the positive effect of HBT on the decolorization degree, this can be rationalized considering that the laccase/HBT system, which is al so effective through the formation of a free radical, is a stronger oxidant than laccase itself $(+1.084 \mathrm{~V}$ vs NHE) (26). Thus in the oxidative dye decolorization approach using laccase or laccase/mediator, the redox potential difference between the biocatalyst and the dye is a relevant indicator whether the enzyme is able to decolorize the dye.

Decolorization by I. occidentalis. I onizable azo dyes are impermeant to cell membranes and their transformation by living microbial cells must thus occur in the extracellular medium (27). Azo dyes can be reduced by two or four electrons to produce usually colorless hydrazo compounds or amines, respectively (28). In the case of bisazo dyes the reduction of the azo bonds occurs consecutively (29). The substituents next to the azo bond 
Table 2. Times of Maximum Decolorization ( $\geq 98 \%$ ) by Yeast Strain I. occidentalis and Reduction Peak Potentials (vs NHE) of Tested Azo Dyes

\begin{tabular}{|c|c|c|}
\hline dye & $\begin{array}{c}\text { time }(h) \text { for } \max \\
\text { decolorisation }(\geq 98 \%)( \pm S D)\end{array}$ & $\begin{array}{l}\text { reduction } \\
\operatorname{peak}^{a}(\mathrm{~V})\end{array}$ \\
\hline $\begin{array}{l}\text { I } \\
\text { II } \\
\text { III } \\
\text { IV } \\
\text { V } \\
\text { VI } \\
\text { VII }\end{array}$ & $\begin{array}{r}8 \pm 1 \\
8 \pm 1 \\
24 \pm 3 \\
30 \pm 4 \\
15 \pm 2 \\
38 \pm 5 \\
45 \pm 5\end{array}$ & $\begin{array}{l}-0.191 \\
-0.131 \\
-0.315 \\
-0.354 \\
-0.270 \\
-0.408 \\
-0.478\end{array}$ \\
\hline
\end{tabular}

${ }^{1}$ Potentials were recorded vs $\mathrm{Ag} / \mathrm{AgCl}(3 \mathrm{M} \mathrm{NaCl})$ and corrected to NHE. ${ }^{2}$ Concentration $0.97 \mathrm{mM}$. ${ }^{3}$ Concentration $1.01 \mathrm{mM}$.

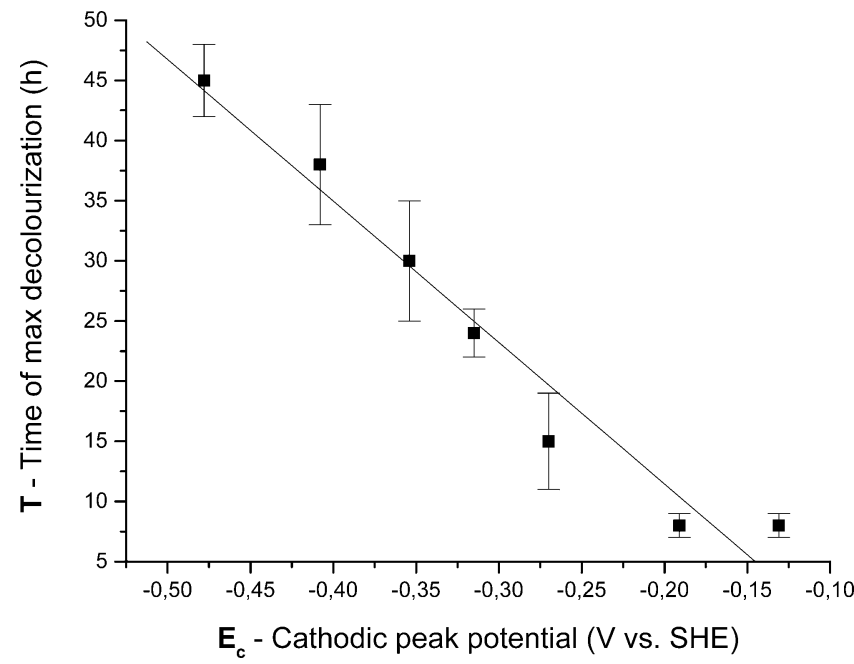

Figure 3. Correlation between cathodic peak potential $\left(E_{c}\right)$ and time of max \% decolorization of dyes. Correlation: $T(\boldsymbol{\square})=(12.1$ $\pm 3.7)+(-117.6 \pm 11.3) E_{c}, r^{2}=0.97, S D= \pm 3.3$

affect the rate of azo dyes reduction (30). The process is also facilitated by redox mediators (31).

Previous work with yeasts has shown that azo dyes are reduced to amines (19). In this work we investigated the possibility of using data obtained by cyclic voltammetry to predict relative decolorization rates of azo dyes by I. occi dentalis. Our approach was to measure the times required for $\geq 98 \%$ decolorization of the dyes (Table 2 ). As seen in Figure 3, an approximately linear correlation was observed between the decolorization times and the cathodic peak potentials of the tested dyes.

Concerning cell-mediated reductions, NAD $(\mathrm{P}) \mathrm{H}$ is generally assumed to be the primary electron donor. The driving force for the reduction reactions promoted by $\mathrm{NAD}(\mathrm{P}) \mathrm{H}$ will therefore be proportional to the difference between the reduction potentials of the donor and acceptor species: the less negative the redox potential of the azo dye, the more favorable (and faster) will be its reduction $(32,33)$. We confirmed this principles in our observations.

\section{Conclusions}

We found a linear relationship during the initial period of decolorization with laccase and a laccase/mediator system between the percentage decol orization of each dye and the respective anodic peak potential.

Contrarily to the laccase system, I . occidental is decolorizes azo dyes through a reductive mechanism, but also in this system a linear relationship between the cathodic peak potentials and the time of maximum decolorization of the azo compounds was observed.
The redox potential differences between the biocatalysts and the dyes is a relevant indicator whether the enzyme is able to decolorize the dye.

\section{Acknowledgment}

We would like to thank the European PRAXIS XXI SFRH/BD/4720/2001 project for providing the grant to A.Z. and the European BIOEFTEX project for providing a grant to P.R.

\section{References and Notes}

(1) Kimura, M. Prospects for the treatment and recycling of dyeing wastewaters. J. Soc. Fiber Sci. Technol. J pn. 1980, 36, 69-73.

(2) Robinson, T.; McMullan, G.; Marchant, R.; Nigam, P. Remediation of dyes in textile effluent: a critical review on current treatment technologies with a proposed alternative. Bioresour. Technol. 2001, 77, 247-255.

(3) Ogawa, T.; Yatome, C.; I daka, E. Biodegradation of $\mathrm{p}$ aminoazobenzene by continuous cultivation of Pseudomonas pseudomallei 13NA. J . Soc. Dyers Colourists 1981, 97, 435438.

(4) Idaka, E.; Ogawa, T.; Horitsu, H. Reductive metabolism of aminoazobenzenes by Pseudomonas cepacia. Bull. Environ. Contam. Toxicol. 1987, 39, 100-107.

(5) Stolz, A. Basic and applied aspects in the microbial degradation of azo dyes. Appl. Microbiol. Biotechnol. 2001, 56, 6980

(6) Chung, K. T.; Cerniglia, C. E. Mutagenicity of azo dyes: structure activity relationship. Mutat. Res. 1992, 277, 201220.

(7) Robles, A.; Lucas, R.; De Cienfuegos, A. G.; Galvez, A. Phenol-oxidase (laccase) activity in strain of the hyphomycete Chalara paradoxa isolated from olive mill wastewater disposal ponds. Enzyme Microb. Technol. 2000, 26, 484-490.

(8) Bourbonnais, R.; Paice, M. G.; Freiermuth, B.; Bodie, E.; Borneman, S. Reactivities of various mediators and laccases with kraft pulp and lignin model compounds. Appl. Environ. Microbiol. 1997, 12, 4627-4632.

(9) Chivukula, M.; Renganathan, V. Phenolic azo dye oxidation by laccase from Pyricularia oryzae. Appl. Environ. Microbiol . 1995, 61, 4374-4377.

(10) Srebotnik, E.; Hammel, K. E. Degradation of nonphenolic lignin by the laccase/1-hydroxybenzotriazole system. J . Biotechnol. 2000, 81, 179-188.

(11) Fabbrini, M.; Galli, C.; Gentili, P. Comparing the catalytic efficiency of some mediators of laccase. J. Mol. Catal. B: Enzym. 2002, 16, 231-240.

(12) Bourbonnais, R.; Paice, M. G.; Freiermuth, B.; Bodie, E.; Borneman, S. Reactivities of various mediator and laccase with kraft pulp and lignin model compounds. Appl. Environ. Microbiol. 1997, 63, 4627-4632.

(13) Xu, F. Oxidation of phenols, anilines, and benzenethiols by fungal laccases: Correlation between activity and redox potentials as well as halide inhibition. Biochemistry 1996, 35, 7608-7614.

(14) Xu, F.; Deussen H. J. W.; Lopez, B.; Lam, L.; Li, K. Enzymatic and electrochemical oxidation of N-hydroxy compounds. Eur. J . Biochem. 2001, 268, 4169-4176.

(15) Goyal, R. N.; Verma, M. S.; Singhal N. K. Voltammetric investigations of the reduction of direct Orange-31 a bisazo dye. Croat. Chem. Acta 1998, 71, 715-726.

(16) Furniss, B. S.; Hannaford, A. J .; Smith, P. W. G.; Tatchell, A. R. Vogel's Textbook of Practical Organic Chemistry, 5th ed.; Longman Group UK, Ltd.: Essex, 1989; p 951.

(17) Zille, A.; Tzanov, T.; Gübitz, G. M.; Cavaco-Paulo, A Immobilized laccase for decolourisation of Reactive Black 5 dyeing effluent. Biotechol. Lett. 2003, 25, 1473-1477.

(18) Martins, M. A.; Cardoso, M. H.; Queiroz, M. J .; Ramalho, M. T.; Oliveira-Campos, A. M. Biodegradation of azo dyes by the yeast Candida zeylanoides in batch aerated cultures. Chemosphere 1999, 38, 2455-2460.

(19) Ramalho, P. A.; Scholze, H.; Cardoso, M. H.; Ramalho, M. T.; Oliveira-Campos, A. M. Improved conditions for the 
aerobic reductive decolourisation of azo dyes by Candida zeylanoi des. Enzyme Microb. Technol. 2002, 31, 848-854.

(20) Xu, F. Effects of redox potential and hydroxide inhibition on the $\mathrm{pH}$ activity profile of fungal laccases. J . Biol. Chem. 1997, 272, 10924-928.

(21) Bourbonnais, R.; Leech, D.; Paice, M. G. Electrochemical analysis of the interactions of laccase mediators with lignin model compounds. Biochim. Biophys. Acta 1998, 1379, 381390.

(22) Clark, W. M. Oxidation-Reduction Potentials of Organic Systems; Williams \& Wilkins Co.: Baltimore, MD, 1960; pp 471-514

(23) Pasti-Grigsby, M. B.; Paszczynski, A.; Goszczynski, S.; Crawford, D. L.; Crawford, R. L. Influence of aromatic substitution patterns on azo dye degradability by Streptomyces spp. and Phanerochaete chrysosporium. Appl. Environ. Microbiol. 1992, 58, 3605-3613.

(24) Call, H. P.; Mucke, I. History, overview and applications of mediated lignolytic systems, especially laccase-mediatorsystems (Lignozym process). J . Biotechnol. 1997, 53, 163202.

(25) Xu, F.; Shin, W.; Brown, S. H.; Wahleithner, J. A.; Sundaram, U. M.; Solomon, E. L. A study of a series of fungal laccases and bilirubin oxidase that exhibits significant differences in redox potential, substrate specificity, and stability. Biochim. Biophys. Acta 1996, 1292, 303-311.

(26) J ohannes, C.; Majcherczyk, A. Natural mediators in the oxidation of polycyclic aromatic hydrocarbons by laccase mediator systems. Appl . Environ. Microbiol . 2000, 66, 524528.
(27) Pearce, C. I.; Lloyd, J . R.; Guthrie, J . T. The removal of colour from textile wastewater using whole bacterial cells: a review. Dyes Pigments 2003, 58, 179-196.

(28) Hu, T. L. Decolourisation of reactive azo dyes by transformation with Pseudomonas I uteola. Bioresour. Technol. 1994, 49, 47-51.

(29) Goyal, R. N.; Minocha, A. Electrochemical behaviour of the bisazo dye Direct Red 81. J . Electroanal. Chem. 1985, 193, 231-240

(30) Suzuki, T.; Timofei, S.; Kurunczi, L.; Dietze, U.; Schuurmann, G. Correlation of aerobic biodegradability of sulfonated azo dye with the chemical structure. Chemosphere 2001, 45, $1-9$.

(31) Keck, A.; Klein, J.; Kudlich, M.; Stolz, A.; Knackmuss H. $\mathrm{J}$.; Mattes R. Reduction of azo dyes by redox mediators originating in the naphthalenesulfonic acid degradation pathway of Sphingomonas sp. strain BN6. Appl. Environ. Microbiol. 1997, 63, 3684-3690.

(32) Bragger, J . L.; Lloyd, A. W.; Soozandehfar, S. H.; Bloomfield, S. F.; Marriott, C.; Martin, G. P. Investigations into the azo reducing activity of a common col onic microorganism. Int. J. Pharm. 1997, 157, 61-71.

(33) Semde, R.; Pierre, D.; Geuskens, G.; Devleeschouwer, M.; Moes, A. J . Study of some important factors involved in azo derivative reduction by Clostridium perfringens. Int. J. Pharm. 1998, 161, 45-54.

Accepted for publication May 10, 2004.

BP049963। 